\author{
Milan Milojkovic** \\ University of Novi Sad, \\ Academy of Arts, Department of Music
}

\title{
PILGRIMAGE THROUGH A SOUND HORIZON - A GUIDE THROUGH THE ELECTROACOUSTIC WORKS BY VLADIMIR JOVANOVIĆ (1956-2016)
}

\begin{abstract}
In this paper, I aim to create a compiled analytical description of electroacoustic works by the untimely deceased composer Vladimir Jovanović, created between 2002, when he was appointed as manager of the Electronic Studio of III program of Radio Belgrade, and 2015, when he left this post. During this time, the author created seven studio compositions, almost exclusively using a computer. Thus, the focus of this paper will be placed on peculiarities of his compositional techniques - especially when working with MIDI and samples. The base for the formation of the narrative about Jovanović's works will be his statements, recorded in a radio interview and program notes he wrote as accompaniment to his compositions, together with the musicological and theoretical writings of Serbian authors.
\end{abstract}

Key words: electroacoustic music, computer music, MIDI, sample, Electronic studio, Vladimir Jovanović

* Author contact information: milanmuz@gmail.com 


\section{Introduction}

Although the immediate and sad occasion for the writing of this text is the untimely death of the composer Vladimir Jovanović, an insight into his oeuvre may also yield important information about the development of electro-acoustic music in Serbia, not only during the 2000 s, but also since the founding of the Electronic Studio of Radio Belgrade 3. Jovanović's tenure at the Studio coincided with the most difficult period in its history, but he nonetheless worked diligently to preserve it from (further) decline, running the Studio after it reopened in $2002 .{ }^{1}$

Jovanović's oeuvre is the work of a man who surveyed his time and surroundings with a religious kind of serenity and a rare gift to articulate his observations digitally and unequivocally, again using original means and procedures and revealing previously unknown capabilities of long forgotten and "obsolete" hardware. He often submitted his pieces to competitions such as Prix Italia and the International Electroacoustic Music Festival in Bourges; interestingly, although an exquisite connoisseur of audio technology, he invariably recorded his works, all of them, down to the last one, using magnetic tape, which is now stored in the Studio's archive. He won the Composers' Association of Serbia award for his symphonic poem Moreuzi (Sea Straits). I was fortunate enough to have an opportunity to collaborate with Jovanović and record a conversation we had at the Electronic Studio on 12 March 2012, which was subsequently broadcast (although in an abridged version) as part of Radio Belgrade 3 timeslot titled Elektronski studio (Electronic Studio) on 25 March 2012, to which I will refer multiple times in the remainder of this text. Jovanovic supplied me with recordings of his final works (Ornitofonija, Odblesci $i$ odzvuci horizontal, and Zdravo Džek Di, kako si?) Jovanović on a CD so they could be premièred on the radio, complete with a commentary by the author, which constitutes a rare example of auto-poetic explication by this modest but extraordinarily gifted composer.

\section{Jovanović and Postmodernism}

All the works that Vladimir Jovanović produced during this period correspond with concepts of postmodernism that may be found in Serbian musicological thought. In that regard, Vladan Radovanović proposed a subdivision of postmodernism into a higher, esoteric kind of postmodernism - the one that rests primarily on models inherited from the history of the avant-garde, or, more broadly, modernism, or art music in general - and a lower, exoteric kind, whose expression would also integrate elements of other levels of musical hierarchies, popu-

1 From 1999 to 2002 the Studio was out of operation. 
lar music, folklore, applied music, etc. ${ }^{2}$ Both of them are found in Jovanović's oeuvre, although one could also ask how clearly one might differentiate between them in that context, the way Radovanović proposed to do. On the other hand, in addition to these two categories, Miško Suvaković also distinguishes a third category: simulation music or techno-postmodernist music, which he apparently defines by reference to its technological mode of being, which may (and does) include the former two categories, since the entire process of production in techno culture rests on the same principles. ${ }^{3}$ Therefore, the remainder of this essay is

2 Vladan Radovanović, Muzika i elektroakustička muzika, Novi Sad, Izdavačka knjižnica Zorana Stojanovića, 2010, 101.

3 "Postmodern music is defined as the multiplicity of mutually inconsistent productions and therefore the following models are distinguished: 1) esoteric, eclectic, and post-historical postmodern music; 2) exoteric and eclectic postmodern music, and 3) simulation music or techno-postmodern music.

1. It is characterized by rejecting the notion of the project of progress, formal innovation, and literal essentialist constitutive sound, in favour of a fictional, qua textually orientated sound that exhibits its capability of presenting or representing historical, stylistic, and generic formulations of musical expression and presentation... Music, in all its variants of existence (the relativization of the musical invariants of style, genre, technique) as an art and, especially, social activity, becomes a demonstrative and manipulative code of postmodern presentation, usage, or production. The musical work presents another music, from quotation, via collage, montage, and simulation, to the mimesis of music as an art, institution, world, culture, or history.

2. Exoteric music highlights the procedures of the inter-musical as a form of switching from one current system of production, phenomena, institutions, styles, or music as an art into another. It is anti-essentialist not by virtue of highlighting the non-existence of any essential traits of a given system of music as opposed to others, but by pointing to the morphing of one family of similarities into other families or even cultural patterns.

3.1. Simulation music or techno-postmodern music emerges in three systems of music qua techno-linguistic games... Music is no longer, in modernist terms, an autonomous, closed discipline and institution, but a form of hardware and software realization of various perceptions of social and cultural reality. 3.2. Directing attention, interest, and labour to technique (metaphorically or, in some cases, literally to hardware and software) effects a turn from eclectic semiological post-historicism toward enjoying the very ontology of the media of music; this type of music seemingly begins to resemble Modernism, but differs from it by virtue of its media and rhetorical multiplicity (techno-media and rhetorical complexity), which is realized by means of the simulation techniques of computer processing of digital and analogue information. 3.3. Music turns into a system of electronic information relayed through interfaces between biological and electronic systems, which means that the notion of music is no longer ontologized through the autonomy and specialization of the sense of hearing but a direct connection with electronic impulses, producing an anaesthetic type of musical perception". Miško Šuvaković, Pojmovnik savremene umetnosti, Beograd, Orion art, 2011, $559-560$. 
focused on the first, esoteric postmodernist axis, given that Jovanović's oeuvre for the most part remained close to it, while special attention will be devoted to the "simulation" technological aspect with which his oeuvre corresponded, as well as to certain elements of the exoteric that may be identified in his work.

Jovanović entered the musical scene in the heat of the postmodernist late 1980 s, but nonetheless always remained close to the heritage of the avant-gardes, especially musique concrète. In that regard, it is pertinent to highlight the following insights from Mirjana Veselinović Hofman: "in its concrete application, the compositional procedure, fetishized in the avant-garde as the basic guarantee of fulfilling its obsession about creating new sonic 'regulations', moves and transforms its semioticity as its characteristic trait from the age of the avant-garde onto the predominantly semantic plane of post-modernity. In it, it sheds its normativistic burden, entering into free competition with procedures of all other origins. It gave it a different meaning, affecting its belief in its own self-sufficiency and self-fulfilment by directing it to the uniqueness and singularity of the work and driving it away from desiring power through norm and domination", which is to a significant degree applicable to Jovanović's works, as shown below. ${ }^{4}$

\section{The Context of Serbian Electro-acoustic Music at the Beginning of the 2000s}

The emancipation of the computer as a live performance instrument, which in Serbian electro-acoustic music occurred during the 1990s, culminated with Serbia's first concert involving live electronics and orchestral music, a piece by Jasna Veličković titled Vris.Krik.exe, composed in 2000. However, this work, although arguably the culmination in the treatment of live electronics in Serbian music, actually marked the beginning of a new stage in the development of Serbian electro-acoustic music in the opening decade of the new millennium, precisely by conquering these domains of "playing music on a computer".

Namely, in the early 2000s, electro-acoustic composition certainly called for a computer as a basic means of work (along with the necessary peripheries, audio interfaces, controllers, and the like), a situation that was hardly different from the 1990s; however, there are indications that the focus in using computers moved from technology "itself" to performativity as the main goal, primarily referring to the concept of the work of art, whereas ways and techniques of realizing it moved to the background, as "tools". In a number of their works, the authors assembled around the theoretical platform Teorija koja hoda / Walking

4 Mirjana Veselinović Hofman, Fragmenti o muzičkoj postmoderni, Novi Sad, Matica srpska, 1997, 138-139. 
Theory ${ }^{5}$ demonstrated this paradigm shift giving rise to a different approach to technology as well as to artistic creation in general. At the time, the group comprised young composers, theorists, musicologists, and theatre scholars: Bojana Cvejić, Bojan Đorđev, Siniša Ilić, Jelena Novak, Ksenija Stevanović, Miško Šuvaković, Jasna Veličković, and Ana Vujanović.

It is important to stress that, seen from today's perspective, the broad problematization of the digital that occurred in the early 2000 s seems precisely as the watershed moment between the digital and the post-digital, given that Walking Theory's conceptualizations of the digital in their works and the comprehensiveness of their view of the impact of this technology on art manifest an already well-founded awareness of the digital as an integrated, complete system, ${ }^{6}$ whose theorization made it evident that it was derived from a meta-domain, ${ }^{7}$ that is, from the post-digital field, aware of the reach of a given

5 "Our intent in the Walking Theory project is to explore the space between our respective media, in other words, to relate the artistic, performative act with the theoretical texts that condition, surround, and define it. Regarding interdisciplinarity, which we pursue, we do not seek to identify with alternative or avant-garde tendencies, nor do we belong to them. Our point of departure is an established academic tool, especially in the currently ruling context of post-modernity. What brings our respective media closer together is the domain of theory. In that regard, interdisciplinarity is not a domain of relaxed, facile safety; it effectively begins by tearing down the solidarity of the old disciplines (solidarity means that each discipline gets to keep its own part of the field) for the sake of studying the Text, that is, the situation of theory performance." Group of authors, "Teorija koja hoda (Manifest)", http://www. tkh-generator.net/wp-content/uploads/2014/01/TkH_1.pdf.

6 "The procedures of the social practices of digital technologies are those of generating, simulating, relaying, presenting, and performing information. Generation, simulation, processing, relaying, presentation, and performance are techniques pertaining to the becoming of information or, more accurately, of becoming information. Becoming information is the process whereby the existential body (of the operator, performer, or artist) is removed from the ontology of being (that which is) into the ontology of becoming (that which is beginning to be, but is not yet: only becoming, without being). According to Deleuze, this denotes that which never truly occurred, but which always comes before and is already past. Therefore, the key question for the world of digital technologies is not: "What is virtual reality?" (or the effects of interactive machines), but: "What is the reality of the virtual". Miško Suvaković, "Postajanje mašinom - od teorije preko filozofije digitalne umetnosti, teatra i performansa $i$ natrag", http://www.tkh-generator.net/wp-content/uploads/2014/04/tkh_7-web.pdf.

7 Indeed, the world has changed. With information digital technologies the world has changed - not in terms of becoming better or worse, but becoming multiply potentially different, because there emerged a different kind of relationism in inter-subjective positioning within the networked non-nature of digital systems. And this concerns not only micro-politics, but also different individual micro-politics. This is not to say that digital technologies are the culprit in global/local politics, or that they are innocent, but that they are a necessary 
historical paradigm viewed through technological and artistic concepts. In my view, paradigmatic works that illustrate the musical segment of this group's work include Dream Opera and Dracula Project by Jasna Veličković and her colleagues during the early 2000s. Still, one cannot see a more consequential mutual impact between these works and those of Jovanović.

Instead, his work arguably stems from the techniques and methods pursued at the Studio by its founders, Vladan Radovanović and Paul Pignon, and later further developed by Miloš Petrović, Ljudmila Frajt, and others, who viewed the electro-acoustic medium primarily in terms of enabling the realization of works featuring unique, peculiar sonorities and structures. One may say that Jovanović retained this fascination with sound synthesis as a constant but applying it in a digital environment, which was, while anachronistic, still significantly more potent than that of the 1980s and '90s. This effected a breakthrough in the composition process, conditioned as it was at the Electronic Studio by the capabilities of its hardware, which means it was not easy to transcend the division between manipulating recorded material and synthesizing sound, despite attempts to do just that, for instance, in Radovanović's Timbral (1988), Mix (1998), and other works. At the beginning of the 2000s, the situation at the Studio was not encouraging at all. Years without any investment whatsoever, the main synthesizer Synthi 100 out of operation, and antiquated equipment made the Studio a rather discouraging environment for composers. On the other hand, Jovanović was an author for whom precisely such a studio would prove inspiring. At his disposal were "only" a PC with M-Audio sound interface, a MIDI keyboard, and $\log$ ic Pro software, but even with that equipment, this proficient author managed to accomplish extremely complex sound structures, which, bearing in mind the conditions in which they were produced, still seem impressive, regardless of the daily "discoveries" in the field of digital sound synthesis.

\section{The Magnificent Supermarket}

Vladimir Jovanović first caught the attention of the Serbian music public as a member of a group of composers ironically named 7 veličanstvenih (The Mag-

constituent of all current politics, with all the performance consequences that those politics bear. Digital ITC systems generate the artificial dynamic tissue through which a new macroand micro-doxa come to be, within which political procedures are performed. On the other hand, digital technologies move from the domain of determination into that of indetermination and thereby cause cracks in the systems of totalitarian controls, regulations, and deregulations of life. The Lacanian not-whole, Guattarian heterogeneous, and Badiouan multiple become important political-technological traits of the un-attainability of constantly emerging-as-totalizing social practices in actuality. 
Milojković, M.: Pilgrimage Through a Sound Horizon - a Guide Through the...

nificent 7), which also included Ana Mihajlović, Isidora Žebeljan, Nataša Bogojević, Igor Gostuški, Ognjen Bogdanović, and Srđan Jaćimović. Although the group presented themselves together, at a joint concert held at Belgrade's Students' Cultural Centre on 27 May 1988, one could hardly say that its members had much in common in terms of their creative work. It seems that they all shared a tendency to incorporate sounds from other musics or extra-musical elements in their works, ${ }^{8}$ as well as a prominent streak of postmodern communicativity. This early period saw Jovanović's first work that generated a considerable reaction from the public, his Supermarket simfonija [Supermarket Symphony]. The piece was made at the Electronic Studio of Radio Belgrade 3 and already showed elements of sound organization and manipulation that Jovanović would elaborate more thoroughly during the 2000s.

The basis of Supermarket simfonija, as implied in its title, is a critique of consumerism communicated by means of musique concrète. Jovanović used sounds from everyday life as well as samples of compositions by great masters and juxtaposed them, striving to mould or transform them into entirely new sonorities. In a certain sense, Jovanović's procedure may be likened to similar procedures in sculpture, whereby works are fashioned using already available materials from everyday life (as in trash art). The work also demonstrated Jovanović's closeness to the ideas of Pierre Schaeffer, which Jovanović often stressed himself. Although Supermarket simfonija is not an acousmatic work, ${ }^{9}$ its techniques and principles of working with the material are identical to the ones that the Groupe de recherches musicales (GRM) had cultivated for decades. ${ }^{10} \mathrm{How}-$ ever, in terms of poetics, it seems that in this piece Jovanovic "stood" closer to the views of Luc Ferrari, who began his career as a member of GRM, but later left the group to pursue a deliberately descriptive character in his works, abandoning acousmatic principles. In that sense Jovanović's piece is strongly

8 Melita Milin, "From Communism to Capitalism via War: Landscape of Serbian Music 1985-2005", Muzikologija, 2008, 8, 94.

9 In Vesna Mikić's summary: "essentially a generic term, acousmatics, stems all the way from Pythagoras, while the adjective acousmatic was used by author Jérome Peignot in an attempt to describe sounds that are heard, but whose source is hidden in concrete music. Then came chapter four of Schaeffer's Tractatus on Musical Objects titled "Acousmatics", before François Bayle in 1974 introduced the term acousmatic music"; Vesna Mikić, Muzika u tehnokulturi, Beograd, Univerzitet umetnosti u Beogradu, 2004, 135.

10 Concrete music is based on "pre-existing, borrowed elements of whatever kind of sound material - noises or musical tones that are experimentally put together, through direct editing, in order to fulfil the decision to draft a composition without using traditional musical notation"; Pierre Schaeffer, In Search of a Concrete Music, Berkeley, University of California Press, 2012, 35. 
engaged, so even though it manifests a strong logic of a "purely" musical shaping of contents, the meaning of the samples featured in the piece is not abstracted, that is, they are not used solely on account of their specific sound qualities. However, this is where an ironic intervention by Jovanović comes to the fore, since samples from art music should "by nature" carry only musical contents, but in a consumerist environment, they become a mass consumption commodity sitting on a supermarket shelf. From today's perspective, it seems that this piece has "aged well", given how realistic its "irony" has become, down to the smallest detail that few could (or dared) imagine.

One may say that the destruction of the 1990s wars made the strongest impact precisely on this generation of composers. Many of them no longer aspired to work as composers, while those who still did often decided to pursue music abroad. During this period, Jovanović withdrew from active composition and devoted himself to explorations in spirituality, which took him to Mount Athos.

\section{The Return to the Electronic Studio}

When Jovanović returned to the Electronic Studio, one could say that Serbia's musical scene was no longer the one that saw the emergence of Supermarket simfonija. However, since the pace of historical change is not the same everywhere, the Electronic Studio of Radio Belgrade 3 remained, in terms of technology, much the same as it was when Jovanović left it. On the other hand, the people once assembled by this institution no longer showed any interest in this, one of Serbia's many cultural institutions suffering from years of neglect. Faced with such a situation, one had to start from scratch. Jovanovic found some of the Studio's digital hardware intact, still working, which enabled him to begin composing new works very soon, immediately upon his return.

In fact, during his initial years at the Studio, Jovanović compiled a sizeable database (comprising samples and their meta-data), ${ }_{11}^{11}$ which he used in a rather peculiar way, treating the DAW (digital audio workstation) like a virtual studio/ instrument allowing him to fully realize his conceptions. The type of composition process that he developed during this period might be described as basically improvisational in nature, since this kind of spontaneous invention was a domain of his passionate research, not only in art music, but also in jazz, rock, folk, and sacred music performing practice. Therefore, in most of his pieces, sequencing resulted from improvisatory sessions where a series of abstract values (MIDI information packages) were created, which determined the pitch and temporal

11 The computer that Jovanović used is stored in the Electronic Studio's archive, with all of the data found in it, and remains available to all those who are interested in Jovanović's work. 
Milojković, M.: Pilgrimage Through a Sound Horizon - a Guide Through the...

distribution of the sound events. Sound synthesis was then undertaken whilst listening carefully to the behaviour of the "triggered" sample in its new surroundings and often rested on modelling sound after physical models and intervening in the sonic spectrum. However, meticulous work on micro-structures, which characterizes every finished piece, prevents the analyst from reaching generalizing conclusions, since creativity in devising compositional strategies was an important feature in Jovanović's oeuvre, which means that those strategies very much differ from one piece to the next. On the other hand, at this time Jovanović's work was not closely related to the ruling tendencies of contemporary electronic music, since he neither used live electronics nor (any longer) engaged in deconstructing grand narratives by sampling, nor was he close to the thinking of the youngest generation, who saw the computer only as a tool in their pursuit of performativity, which was already discussed above.

In light of all that, it is hard to draw a line when exactly the concept of postmodernist computer music ended in Serbian music, since, although composers after 2000 showed little interest in it, Jovanović retained it as his only mode of composing right up to 2015 .

\section{From "Nature" to the "Nature" of Sonority}

The first work that Jovanovic produced following his return to the Studio is a cycle titled Tragovi sna o dalekom nebu [Traces of a Dream about the Distant $S k y]$, inspired, according to the author, by falling asleep and the "peculiar logic of dreaming". The cycle comprises 15 movements, in a fixed order due to the nature of the recording, although the author in fact envisaged a randomized reproduction, allowing the listener to arrange the movements in whatever order they prefer and thus arrive at their own impression of the piece as a whole. This peculiar quasi-aleatoric conception takes the listener into the "work", at the same time turning her into a participant in the performance as well as rendering her responsible for her own perception of the result. Of course, Jovanović envisaged that the piece would be reproduced not from tape but from a $C D$, since most CD players include the shuffle option, playing the tracks in a random order. In this way, the author "bypassed" the obstacle that recording puts before aleatoric procedures, confronting the listener with an option that was (already) at her disposal. In that sense, the CD player reproducing the work likewise participates in its performance. The composition features an extremely broad range of synthesized sonorities, whose transformations through time and the panorama of the work reveal Jovanović's virtuosic mastery not only of the DAW, but also of synthesizing and mixing techniques. The development technique used in this piece is the variation technique, while the "subject" of the variations appears 
in full only in the $15^{\text {th }}$ movement. However, the author stresses that a complete exposition of the subject is part of his own perception of the piece and allows for the possibility of reproducing that movement at the beginning, following the listener's wishes or the vicissitudes of chance. Moreover, each movement appears as a world of sounds in itself, or a moment of sonoristic improvisation captured in time, condensed around a prominent sonic manifestation, such as quasi-pianistic motoric preluding, processing of noises, and, especially, processing and mutation of samples. Namely, in this context, model [uzor $]^{12}$ may be taken to denote an individualized notion of the acousmatic musical work derived from the GRM's later activities, although it is not especially conceptualized but rather, one may say, immanent to Jovanović's poetics. Every sample is treated as a model, and this sort of "absolute progression" may also be understood as a consequence of improvisation. On the other hand, the author distributes the samples precisely based on the result of elaborating the initial set of samples and the entire sound flow thus often seems like a carefully shaped, heterogeneous but coherent mass, whose future flow depends only on the development taking place at any given time.

Standard formal types hardly apply to this or other works by Jovanović. Radovanović's "fish-like" form is only hinted at, while the form of Jovanović's works might be easier to discern in terms of emulating (a conception of) nature, or life, through digital sonorities. Namely, as the author himself asserts, natural phenomena - "in this nature" - are fascinating, but often also destructive, so he tends to communicate his understanding of the nature of a given sounding by means of a whole shaped on the basis of that sounding, in order to allow man to use this specific aesthetic perception of a model of nature to perhaps come closer to other and/or his own nature. However, in Jovanović's view, destruction is precisely what drives the mutations of sound entities, the initiator of development, and starting point of the variation process. Deconstructing (the perception of the nature of) a sample, most often following the principle of working with a model, initiates an almost narrative process, whose narration concerns the morphology of a given sounding.

12 According to Veselinović Hofman, the main methods of compositional work in postmodern music include sampling and modelling, with the latter term denoting two different approaches. A sample or pattern [mustra] appears as a certain material representing its original context by exhibiting its most typical properties, which characterize it. Consequently, model may denote a sample used by the composer in a given work, while it may also denote a model qua concrete material, noting some of its properties (e.g. structure, texture, timbres), which the composer then uses or even challenges in her individual expression; $c f$. Mirjana Veselinović Hofman, Fragmenti o muzičkoj postmoderni, Novi Sad, Matica srpska, 1997, 25-28. 
Milojković, M.: Pilgrimage Through a Sound Horizon - a Guide Through the...

The texture of Tragovi sna is multilayered and, one may say, mostly instrumental, since one easily distinguishes between individual lines of percussive, "piano-like", and quasi-string sounds of the "underbelly" of the piece and the sparkling clouds of smaller sonorities that fill the upper parts of the spectrum. Apart from vertical distribution, the horizon also participates in building the flow, which means that the voices' appearances are not only temporally but also spatially defined. As the author emphasized, the work was inspired by the "logic of dreams", which means that its quasi-improvisatory structure is precisely a consequence of applying such a logic to the distribution of sound events, which, in terms of the work's micro-form, still mostly follow their own "nature" of development. The piece is replete with "fantastic" sounds, i.e. shifting "metallic" objects with ample reverberation, which generate its dreaming atmosphere, i.e. the atmosphere of being removed from concrete reality. This is also enhanced by the rhythmic component, which is ostinato-like at almost every level, with rhythmic patterns established at the beginning of the movement typically continuing unbroken to the end, unfolding in an extremely complex poly-rhythm. It is underscored by the clearly differentiated timbral characters of individual lines, which in this piece do not "morph" into one another, but consistently remain carriers of counterpoint.

\section{Domaćine, press button to start game}

Communicability in presenting sonic ideas was probably a constant feature in Jovanović's works already in Supermarket simfonija. The subtle irony of that piece assumes an unequivocal form in the triptych Hodočašce $u$ vrtove praznine [A Pilgrimage to the Gardens of Emptiness] composed in 2008, whose opening sample is a 20 -second segment of a lazarica song, "Otvor' porte, domaćine" ("Open the gates, dear host") from the older rural tradition of Serbian folk songs, and may be regarded as the work's main protagonist. As the author asserts, the "dramaturgy" of the work is meant to illustrate the process of acculturation - i.e. (not) thinking about (one's own) identity. There is much effort in the piece to determine to what extent an identity may be changed and still remain recognizable. Namely, following the initial exposition of its full dynamic and spectral potential, this segment sets out on a journey across quite heterogeneous regions of sound, where its peculiar mimicry, i.e. ability to "merge" with the environment, comes to the fore. In the opening, the sample of the song gradually becomes discernible from the crackling of fire, whose increasingly dense flickering, following a brief cumulation, leads to a responsorial dynamic plateau featuring samples "flying" from one end of the panorama to the other, generating an impression of disorientation. This ambiance is associated with the "rural" idyll, i.e. living in harmony with nature, whereas in its next appearance, the song accompanies an attack by a 
pack of wolves and the melody moves from fire to water and then to air, before flying away with a flock of birds. In each one of these situations, the sample is transformed so that its new features correspond to the new environment. Thus in addition to the song sample, the composer illustrates these "genre scenes" with an array of various concrete sounds, i.e. samples of fire, water (whales, dolphins, underwater sounds), animals, wind, etc. The second part of the piece takes the song into the city, an urban environment, surrounding it with the hustle and bustle of crowded streets, factories, and the opera. In this segment, the composer used the same working principle as in the opening, except that the rustic sample's transformations in an urban ambiance are much more intense, making its identity increasingly hard to recognize, as opposed to the preceding, pastoral environment, where the sample "naturally" fit in with the wind, birds, etc. Finally, the drama culminates in the final movement, where the sample's nature "gives birth" to itself, in an analogy to its previous rural and urban experiences, but, as the author asserts, fails, and this failure is manifested in the coda, where the song appears in a video game, i.e. exactly in its true, virtual nature, which is precisely characterized by this moving from one "level" to the next, step by step, and by negotiating different situations that, however real they might appear, remain in the virtual domain. In that sense, the piece gives ample expression to the concept of a "virtual instrument", i.e. a digital sound object identified precisely on the basis of its identity, i.e. the relationship between its recognizibility and flexibility of change. This relationship, as Jovanović demonstrates, is not proportional and depends on the context - in the "country", the sample is drastically modified and yet easier to recognize than in similar situations in the "city". Thus it seems that Jovanović touched upon an important postmodernist issue, which is precisely the identity of musical material, especially when working with digital samples. In other words, if a DAW by its nature enables users to identify according to their own preferences - with the visual appearance of the studio, its components, working with modules, etc. - Hodočašće u vrtove praznine confronts the listener with the consequences of working with such possibilities, i.e. the problem of recognition and persistence. A digital sound object, that is, virtual instrument, may or may not have an audibly recognizable structure, so it is precisely the context that determines how perceptible its structure will be. On the other hand, it seems as if Jovanović suggested that cognizing the nature of sonority lies precisely in examining the relationship between the sample and the environment, i.e. confronting one model with other models, which results in larger or smaller overlaps between a semantic and a certain kind of "acoustic" understanding. 
Milojković, M.: Pilgrimage Through a Sound Horizon - a Guide Through the...

\section{From "Good" to "Concrete" Nature}

The similarities and differences between Jovanović's poetics and Schaeffer's ideas are most notable in Jovanović's piece Bellscapes, which is dedicated precisely to the memory of the "father" of musique concrète, with Jovanović himself classifying the piece as belonging to that genre. As he explains, the reason for turning to concrete music, as well as in the preceding work, lies in compositional techniques, which enable one to discover the nature of sound, which the author thought might bring him closer to uncovering the nature of life, as well as to "universal sounding". In this particular case, this postmodernist revival of concrete music is neither historicist nor neoclassical, because Jovanović borrows no specific techniques from Schaeffer that might be precisely defined in historical terms, but a series of procedures that canonically belong to electro-acoustic and especially computer music. The result of Jovanović's dedication was thus not a composition à la Schaeffer, but an entirely original work. In that sense, Jovanović's strategy here was more akin to that of Radovanović in Undina and Timbral, because these pieces involve turning to the past "in the field", that is, turning to the history of electro-acoustic musical techniques, which are certainly "replicated" in a postmodernist manner. Unlike most of Jovanović's works, which typically exhibit timbral splendour, in this one he focused on the sound spectrum of cast iron bells. In addition to standard techniques of musique concrète, such as accelerating and decelerating, cutting and splicing, reproducing different segments both ways, one may say that Jovanović in this work also "thematized timbre", producing a sort of study of a sample, i.e. a digital electro-acoustic etude. Bellscapes lends prominent expression to the technique of sample control, as well as to processing, so this piece, too, features a unique form. One may regard it as four entities with no subdivisions, or, as Jovanović defined them, four electro-acoustic landscapes. Each one of them came out of a newly discovered sonorous "nature", which conditioned its subsequent formation, like a plant growing from its root. However, this virtual sonic life is not algorithmic in nature and cannot be automated, which means that, on the one hand, the author's organization of the piece is paramount, while, on the other, it results from each individual moment in the piece and a peculiar type of development that cannot be repeated and, as such, it is qualitatively equal to all the other structures in the work, since each one of them is initiated by a special and unique nature (i.e. life). In that sense Jovanović's idea may be viewed as creating a modernist system of organization based on the nature of sounding. In this case, however, there is no systemic organization, no rationalization in terms of ordering sonorities, but only a processual ordering of intuition initiated by identifying the nature of a given sonority. In that sense, the computer is treated as a 
rather complex instrument/medium/tool that gives rise to the work, but it does not assume authorial powers - the transformation processes are not automated, but, following the spirit of musique concrète, woven into the final shape of the piece. Precisely in Bellscapes the focus is on spectral mutations, which were unavailable to Schaeffer in the early years but in Jovanović's piece become the carrier of processuality, the element that "reveals" the author's attitude to a given sonority and the "environment's" reaction to it.

The work titled $A$ bia $i d u$ a features a similar dramaturgy to the one in Hodočašće u vrtove praznine, except that its sample base consists of baby sounds - crying, peeping, screaming, babbling, laughing, etc. - which are confronted with various contexts. Unlike Hodočašce, $A$ bia involves much more work with synthetic sounds, but working with samples is not neglected either; on the contrary, one might say that in this case, too, it is at the forefront. The work features rather peculiar FM sounds, drones richly endowed with layers of simpler oscillations resulting in lavish spectra, wavetable mutations approximating physical modelling, while Jovanović's mastery of synthesizing techniques comes to the fore precisely in this area of designing "three-dimensional" sound objects. The sounds of babies, as a symbol of innocence and purity - as the author put it: "the possibility to achieve something that none of us have achieved, because every newborn baby is potentially a perfect human being, but, as it turns out, there are not too many of those around" - are juxtaposed with sounds of events that constitute "the greater part of being on this planet" - the horrors, catastrophes, lusts, wars. Jovanović asserts that "on the basis of conflict between those two lines of symbolism [he] attempted to construct a larger dramatic whole". ${ }^{13}$

However, the following description of his compositional procedure, supplied by the author himself, appears to reveal an important relation "hidden" between the many layers of his poetics: "In comparison to earlier works, music is not so central here - its character is rather that of accompanying music - while the sounds produced by babies, I transformed them, so I use them, too, also as musical sounds. Some of the sounds were acquired by digital synthesis and I also used samples of traditional instruments". Therefore, one may argue that in this piece Jovanović separates music from the purely semantic layer where the two lines of symbolism confront each other, whereas he sees music as "pure" music, i.e. the pseudo-acousmatic structure of sonority that, together with the semantic layer, makes up a whole, since identical sounds are found in both layers. Still, the musical structure of the work develops by means of special methods

13 Milan Milojković, Elektronski studio (radio programme), broadcast on 25 March 2012 on Radio Belgrade 3, http://www.rts.rs/page/radio/sr/story/1466/radio-beograd-3/1069012/ elektronski-studio-.html. 
Milojković, M.: Pilgrimage Through a Sound Horizon - a Guide Through the...

based on modifications of the samples' acoustic qualities, while articulating the semantic and semiological plane is determined by the meaning and understanding of the sample in its "concrete", i.e. "found" phenomenality, which is the carrier of meaning, that is, symbolism. On the other hand, these layers are compatible, since the development of the music serves the realization of this "surface" semantic layer, forming a structure that might also be considered a non-staged digital opera, therefore a sort of digital oratorio, a kind of evolution of a work of radiophony.

\section{Electro-acoustic Improvisation}

The next work that Jovanović produced at the Electronic Studio of Radio Belgrade 3 is titled Odblesci $i$ odzvuci horizonta (Reflections and Echoes of the Horizon), with the author further qualifying the work in the subtitle as elektroakustički slučajni sešn (electro-acoustic chance session). His programme commentary reads: "the sonic basis of this piece comprises numerous short improvisations, made either by means of digital sound synthesis (subtractive and FM), or by using samples of natural instruments: the flute, oboe, bass clarinet, double bass, and percussion. The work was played and recorded without the awareness of a possible future whole. Improvisations then became templates, from which, now with a certain awareness of a whole, I chose a series of segments ranging in duration from a few seconds to half a minute. The chosen segments were transformed in various ways and organized into a meaningful musical whole. This approach to composition constitutes searching for the source of music, this time in the author's unconscious initial idea and motives. One then arrives at the thought that in one of its dimensions, composition essentially amounts to creative choosing, transposing, and transforming perhaps already existing Pythagorean-Keplerian sonorities and structures". ${ }^{14}$ In other words, Jovanović stresses that composition is preceded by improvisation, whose purpose is to "sound" the samples and synthetic sounds and add them to the database. Composition begins by choosing samples on the basis of a criterion that stems from the conception of the whole, in other words, by searching the database. Selection is followed by modelling, i.e. working with the samples, the process of organizing these musical and sound events, which may be considered composition "proper", or "creative choosing, transposing, and transforming". A similar procedure was used by Radovanović in Fluksus [Fluxus], except that

14 Vladimir Jovanović, programme commentary for Odblesci i odzvuci horizonta, Radio Belgrade 3 Electronic Studio Archive, first broadcast in "Elektronski studio" on 14 April 2013, http://www.rts.rs/page/radio/sr/story/1466/radio-beograd-3/1304056/elektronski-studio-.html. 
Radovanović's insistence on "choir-like" sounds inevitably introduces a sort of "cybernetic" symbolism, which is absent in Jovanović's "purely electro-acoustic" session, since his focus is not selecting and shaping without extra-musical allusions.

In Ornitofonija [Ornithophony], composed in 2014, Jovanović used the possibilities of transforming samples in a way that, on the one hand, reveals a well-versed connoisseur of the nature of various sonorities and, on the other, an innovative improviser whose singular musicality absorbed whatever technology was available, with all of its advantages and limitations. In other words, this is a piece that uses samples of various kinds of birdsong, "isolating" from them information regarding sound (pitch, articulation, and duration) and using it as MIDI information for "calling" other samples. In other words, birdsong is transformed into sounds of symphony orchestra instruments, preserving, on the level of motivic structure, the natural "melodics" of birdsong, the way it was derived from the sample, without modifications. The author then organized the material in the manner of a symphonic piece, in other words, orchestrating and defining specific instrumental situations featuring different ensembles on the basis of melodic and/or timbral similarities. Once again, Jovanović turned to historical heritage, but this time the truly classical heritage of the symphony, realizing it with unusual means of development unfolding on two levels - that of timbre (transforming birdsong into sounds of instruments) and that of organization (with melodic lines and samples sharing the same frequency contours). Here, the model was twofold: on the one hand, birds and their always similar sounding (recognizable, but always different - an ideal of improvisation as early as the Enlightenment), while, on the other hand, the model might also include the symphony genre, still "valorized" in the composer canon as a sign of mastery and being rooted in historical heritage. As in the preceding piece, the samples of birdsong were selected before the composition process began, except that in this instance, pre-composition did not involve improvisation, but working with a database in a "conventional" way. In other words, Jovanović first selected the samples and then processed them in a way that allowed "extracting" from them the required meta-information that could be put in a MIDI signal. Then he switched to the selection of samples of instruments, whereas orchestration, as a procedure, was taken from the canon, since the main idea of the work was to confront natural sounds with "classical" symphonic sound, thus any experimentation with the composition of the ensemble would only blur one's perception of it. Therefore, one might say that working with the samples came before composing, whereas the creative process itself included working with the model in terms of melody and timbre - with birdsong mutating into instruments and motivic fragments cumulating into melodic lines. 
Milojković, M.: Pilgrimage Through a Sound Horizon - a Guide Through the...

Jovanović used a similar method of composition in his final work as well, titled Zdravo Džek Di, kako si? (Hello Jack De! How are you?). The work's subtitle, elektroakustički koncert za bubnjeve posvećen Džeku Di Džonetu [Electro-acoustic Percussion Concerto Dedicated to Jack De Jonette], reveals Jovanović's model in this piece, which shaped both its sample database and principle of organization. Working on this piece, Jovanovic thoroughly researched the method and manner of improvisation of this famous percussionist using a selection of recordings (especially the live recording of a performance with Miles Davis at the Fillmore East festival in 1970). Jovanović was fascinated by polyrhythm occurring in spontaneous performance, in terms of unwritten improvisation resulting in complex layerings of unrelated rhythmic patterns. This was not a new interest, since a similar treatment of rhythm may also be observed in Tragovi sna as well as Odblesci. However, in his electro-acoustic concerto, Jovanović combined his fascination with improvisation with a specific method of sequencing he developed in Ornitofornija. Namely, in Zdravo Džek Di, birdsong is replaced by percussion samples, which are then temporally and spatially distributed. Combining different layers is an important process in structuring this kind of material, since the entire work rests on interrelating different polyrhythmic complexes with one another. On the other hand, the drum samples are quite rich, especially the cymbals, which emphasizes the unfolding of the inharmonic spectrum and offers much potential for transformation. However, unlike in other works by Jovanović, in this piece the focus is not on shaping the spectrum, although quite interesting sonorities do occur as a consequence of superposition. Nevertheless, the focus in this piece is directed on a kind of working with the material that seeks to combine working with the sample and model into an exploration of the nature of improvisation, centering on the segmentation of time and perception of its flow.

\section{Conclusion}

One might say that with Vladimir Jovanović's untimely death in 2016 the story of digital technology in Serbian artistic music came to a symbolic conclusion. On the other hand, of course, that does not mean that this type of technology is no longer represented in Serbian art music, but only that it has changed so much that the analogue/digital division no longer commands the same significance, refocusing from synthesizing and sampling to higher levels of sonification and data processing. Due to the state of the studio where he worked, Jovanović's works are not on the same technological level as those of his (mostly younger) contemporaries, but on the other hand, they are an inexhaustible source of knowledge about this segment of Serbia's musical past, a treasure trove com- 
bining the experiences of several generations of pioneers who took upon themselves the burden of mastering previously unknown regions of technological development, which informs the basis of the world we occupy today. The sound world of Jovanovic's works prophetically reveals the "artificial" nature of our time, unmasking it and removing from it the snobbish glitter of expensive "gadgets", bringing us back to the beginning, to oscillation, harmonics, the already forgotten depths of our digital past, to the freedom of thinking and feeling somewhere in the "gardens of emptiness".

\section{References}

Group of authors, Teorija koja hoda (Manifest) / Walking Theory (Manifesto), http://www. tkh-generator.net/wp-content/uploads/2014/01/TkH_1.pdf

Mikić, Vesna: Muzika u tehnokulturi, Beograd: Univerzitet umetnosti u Beogradu, 2004.

Milin, Melita: "From Communism to Capitalism via War: Landscape of Serbian Music 1985-2005", Muzikologija, 2008, 8, 91-99.

Radovanović, Vladan: Muzika i elektroakustička muzika, Novi Sad: Izdavačka knjižarnica Zorana Stojanovića, 2010.

Schaeffer, Pierre: In Search of a Concrete Music, Berkeley: University of California Press, 2012.

Veselinović Hofman, Mirjana: Fragmenti o muzičkoj postmoderni, Novi Sad: Matica srpska, 1997.

Suvaković, Miško: Pojmovnik savremene umetnosti, Beograd: Orion art, 2011.

Šuvaković, Miško: "Postajanje mašinom - od teorije preko filozofije digitalne umetnosti, teatra i performansa i natrag", http://www.tkh-generator.net/wp-content/uploads/2014/04/tkh_7-web.pdf 